ISSN 2073-4441

www.mdpi.com/journal/water

Article

\title{
Pros and Cons of Adopting Water-Wise Approaches in the Lower Reaches of the Amu Darya: A Socio-Economic View
}

\author{
Maksud Bekchanov ${ }^{1, *}$, John P.A. Lamers ${ }^{2}$ and Christopher Martius ${ }^{1,3}$ \\ 1 Center for Development Research (ZEF), Bonn University, D-53113 Bonn, Germany \\ 2 ZEF/UNESCO (Khorezm) Project, Urgench State University, 220100 Urgench, Uzbekistan; \\ E-Mail: j.lamers@zef.uzpak.uz \\ 3 Inter-American Institute for Global Change Research, 12227-010 São José dos Campos, SP, Brazil; \\ E-Mail: cmartius@dir.iai.int
}

* Author to whom correspondence should be addressed: E-Mail: maksud@uni-bonn.de; Tel.: +49-228-73-4962; Fax: +49-228-73-1889.

Received: 1 March 2010; in revised form: 18 March 2010 / Accepted: 6 May 2010 /

Published: 20 May 2010

\begin{abstract}
The increased frequency of water shortages parallel to growing demands for agricultural commodities in the lower reaches of the Amu Darya River, Central Asia, calls for improving the system-level water use efficiency, by using interventions at the field level. Despite the existence of various best practices of effective water use (defined here as "water-wise options"), they are not widely adopted by farmers owing to high initial costs of investment and lack of the necessary knowledge and skills of a new generation of farmers after the Soviet era. For assessing the potential of several water-wise techniques, key indicators such as water use reduction rate (WURR), economic efficiency (EE), and financial viability (FV) were combined with expert surveys. A SWOT procedure was used to analyze the (dis)advantages, opportunities and constraints of adopting the selected water-wise methods. Results show that the examined options have substantial potential for increasing water use efficiency under promising EE. The various recommendations aim at improving the sustainability of irrigation water use.
\end{abstract}

Keywords: Khorezm region; financial viability; water use efficiency; SWOT; Uzbekistan 


\section{Introduction}

The Khorezm region of Uzbekistan, located in the lower basin of the Amu Darya river, is representative of about 8 million hectares (Mha) irrigated lowlands in Central Asia [1]. Its geographical location at the tail end of the water supply network often does not allow the demand for irrigation, drinking and industrial water to be satisfied in time and space. Since the economy of Khorezm heavily relies on irrigated agriculture, water scarcity directly threatens the income security and livelihood of the rural population and regional welfare. This was evidenced on several occasions during the last decade. Based on an analysis of long-term data, Müller [2] estimated that the probability for the farming population to receive sufficient water decreased from $82 \%$ in 1982 to presently not more than $75 \%$. Forecastings of water supply and the water use by the upstream countries Kyrgyzstan, Tajikistan and Afghanistan, predict an even lower discharge of Amu Darya water in the near future [3]. Moreover, given the anticipated population growth (about $2.5 \%$ annually), and the increasing demand for industrial water, the water demand for agriculture is very likely to increase. The agricultural sector, which uses about $95 \%$ of all water resources, can therefore contribute most to efficient water use, in particular when referring to the present low irrigation water use efficiency both on field level and in the entire system [4].

Furrow and basin irrigation are the most widespread types of irrigation water use in Central Asia; they are characterized by relatively low energy demand but high water consumption. But, if cropland is inadequately leveled, irrigation water is heterogeneously distributed on the field, which can reduce cotton yield by $25-30 \%$ compared to the potential yields [5]. With furrows of $250-400 \mathrm{~m}$ or more in length, high percolation rates, high ground water levels, soil salinity and waterlogging become common [5]. The estimated field level efficiency of furrow and basin irrigation practices varied between $48-55 \%$ and $40 \%$ [6].

The low water use efficiencies at both the irrigation system and field level call for the introduction of new approaches to obtain a more effective use of irrigation water resources. Assuming that only $40 \%$ of the water supplied to the fields reaches the root zone, there seems to be much scope for improving water use in the lower reaches of the Amu Darya. In addition, water efficient practices at the field level reduce the present high pumping and energy costs via indirect water saving in the conveyance system. In contrast, the rehabilitation of canals by lining requires capital investments as high as 1,200 \$/ha [7], which is currently not affordable to farmers.

This study investigates a number of innovations or "best water use practices" to increase water productivity, which are defined here as "water-wise options". Water-wise innovations are options to reduce water losses, maintaining or increasing production (more crop per drop) and increasing water use efficiency in general, and in particular at the field level. Considering the demand for efficient water use on the one side and financial restrictions on the other side, the main objective of the paper is to provide guidelines to farmers and decision makers on water efficient practices by evaluating the technical feasibility and economic efficiency of different water-wise options and innovations such as laser-guided land leveling, drip irrigation, alternate dry, double, and short furrows at the field level in Khorezm. Given the present low level of farm capital, it cannot be expected that the farming population will adopt water-wise options just because they could be beneficial to the environment. To increase the opportunities for an adoption of water-wise practices, these need to be financially feasible, 
ecologically sustainable and match the sociological context. Given the present low linkages between farmers and markets, the generally poor access to capital, the high transport costs to the urban market centers, and the reduced availability of technologies, farmers in Khorezm are not in a position to experiment much. Moreover, the use of water-wise technologies demands more skills and understanding of agriculture than the present practices. Thus, this lack of expertise needs to be dealt with as well. In the past, numerous technical shortcomings have been underlined, whilst equally important is upgrading the managerial skills of the producers that have only sporadically been voiced.

The specific objectives of this study are therefore to (i) assess, through expert assessments, the (dis)advantages of different water-wise options; (ii) select the most feasible options given the conditions of the Khorezm region; (iii) analyze the economic efficiency of each; (iv) determine the best practices with the highest water use efficiency and the least capital requirement; and (v) evaluate the advantages, disadvantages, opportunities and constraints of adopting advanced technologies with the help of a SWOT analysis.

\section{Technical, Socio-economic, and Institutional Aspects of Water Use in the Khorezm Region}

The Khorezm region is characterized by an arid climate where the annual evapo-transpiration of 1,400-1,600 mm per year by far exceeds the annual precipitation of $100 \mathrm{~mm}$ per year [8]. Rainfall occurs predominantly during the fall-winter period, thus, outside the vegetation period, which makes agriculture totally dependent on irrigation.

The economy of Khorezm heavily rests on agricultural production, which is evidenced by its contribution of around $45 \%$ to the Gross Regional Product [9]. About $70 \%$ of the 1.3 million people in the region live in rural areas, and have to cope with high unemployment rates [2]. About $27.5 \%$ of the rural population lives below the poverty line of 1 USD per day. The latter, however, is impacted by water availability, climate change, and pests, as well as political conditions such as an increased competition for water between the up- and the down-stream countries.

The Amu Darya River is the sole source of water in the region, providing about $5 \mathrm{~km}^{3}$ of water annually, but with occasionally sharp decreases in water supply; e.g., in 2000-2001 and 2008 [10]. About $95 \%$ of the supplied water is used in agriculture [4]. In recent years, the increasing annual and seasonal fluctuations in water supply [2] have shown high income risks in agriculture. According to Duhovny and Sorokin [11] and Martius et al. [12], the expected increase in water demand in upstream countries Tajikistan and Afghanistan, in the near future may lead also to a decrease in water availability in the downstream regions such as Khorezm.

The river water is distributed to the agricultural fields through an irrigation network consisting of magistral, inter-farm and on-farm canals. Canals conveying water through different regions are defined as magistral canals. From them, water is distributed via inter-farm canals to the boundary of former collective farms and present WUAs (Water User Associations), and then delivered through on-farm canals to the field level networks [13]. With the exception of about $10 \%$ lined canals [14], the irrigation system consists of earthen canals with an efficiency of not more than 55\% [12]. Especially at the lower hierarchy system levels, hydraulic structures are missing or dysfunctional [4]. Drainage is performed through a network of open ditches and collectors. 
Reforms in agriculture have led to the appearance of a new class of thousands of private farmers instead of the previous few hundred collective farms. The social and organizational structures of the collective farming practices, including the water management, have been abolished alongside with the dismantling of the collective farms [4]. The appearance of multiple actors at the different levels and arenas in the water sector made water management a socio-political process [15] causing unequal water distribution [4]. On-farm irrigation and drainage infrastructure, formerly managed and maintained by collective farms, were left abandoned, making the water distribution an arena of contestation and competition [16,17].

The probability of receiving sufficient irrigation water is very low, especially in areas furthest from the river [2]. Agricultural incomes are also unequally distributed among the rural population. Gurlen, the district with a direct link to the Amu Darya, shows the highest income from agriculture, while agriculture in Kushkupir, the district with the longest distance to the river, generates the lowest income $[9,10]$. Unequal water distribution results in growing - human-made - water scarcity at the tail end of the irrigation system and leads to frequent crop failures [17,18]. The environmental consequences have been growing salinity, waterlogging, desertification, drying of lakes and decline in biodiversity at the tail end of irrigation systems [18]. Poor knowledge of farmers, misguided policies and constraints in technology adoption are considered to be factors influencing land degradation in the region [12]. The Aral Sea catastrophe, which is believed to be a result of irrigation water over-use in Central Asia, is not only creating environmental problems, but continues to threaten the welfare of the agricultural producers through declining yields and incomes [19].

WUAs have been newly established, primarily in the territory of former shirkats [20], to timely supply sufficient water to users, cleaning the canals and drainages within the WUA boundaries, and maintaining the infrastructure. The organizational set-up of a WUA is that of a non-governmental (NGO) structure that should operate to the benefit of its members, i.e., the farmers/water users. Recent studies showed, however, that these WUAs operate as state organizations [21,22] and actually are used by the state to control farmers' activities. Therefore, the water users consider the WUAs as another water administration imposed on them, and not as a way of introducing collective-action water management.

Farmers do not pay directly for their water consumption, but water pricing is expected to be introduced soon in the country. The irrigation sector is still subsidized by the state; this includes the expenses of all water management organizations; only the budget of the WUA is based on fees collected from the members [20]. Price uncertainty is very high due to underdeveloped markets and the commodity processing sector in the region. Hence, the incentives of farmers to increase crop yields are limited.

\section{Materials and Methods}

\subsection{Estimation of the Efficiency Parameters of Water-Wise Approaches}

The potential of different water-wise innovations-laser-guided land leveling, drip irrigation, alternate dry, double, and short furrows and others-was assessed through an expert-knowledge approach. Five experts were interviewed individually and requested to assess the innovations based on 
a series of criteria [6] such as water use reduction rate, yield impact, financial viability, economic efficiency, adaptability to different soil-climate conditions and suitability for the crops dominating in the region. Their assessments were cross-checked with secondary data sources and averaged. The weights for each specific criterion were evaluated via focus group discussions.

After ranking the water-wise methods according to their average weighted value, the most promising ones were selected and assessed in a further analysis that focused on the technical and economic potential while using secondary data sources [5-7]. This resulted in four groups of water-wise options: Group A included a change of the cropping pattern such as replacing paddy rice areas with less water-consuming crops such as maize for staple production (A1) or aerobic rice (A2); Group B included options to increase soil moisture by hydrogel application (B1) or manuring practices (B2) for cotton, wheat, and potato cultivation; Group C contained options to obtain a more adequate water supply such as laser-guided land leveling $(\mathrm{C} 1)$ for cotton and drip irrigation $(\mathrm{C} 2)$ for tomato; Group D covered improved furrow irrigation practices, i.e., surge flow (D1), double furrow (D2), alternate dry furrow (D3), and short furrow (D4) for cotton cultivation.

Hydrogel is a crystal polymer, which is applied around the roots of plants. The polymer absorbs and retains humidity up to 200-times its own dry weight, which is then slowly released for plant growth.

The surge flow technique uses a device supplying water in furrow by intermittence, involving a cycle of flooding and dewatering. As a consequence, a fine layer is established in the previously wetted portions of the furrows where reduced soil intake rates and improved hydraulic characteristics occur almost immediately after the initial dewatering of the soil surface. This phenomenon decreases infiltration rates and enables the water flow to the end of the furrow and field.

Double-sided furrow application provokes a better irrigation of the fields. Since water is applied from both sites of the same furrow, a better uniformity of the water applied over the entire length of the furrow is obtained. In the case of Alternate Dry Furrow (ADF) only each second furrow is irrigated.

Changed values of water use as well as decreased or increased crop yields under different options and simulations certainly bring about altered values of water productivity. Water productivity was estimated as the ratio of output or yield to total water used during irrigation. Due to high salt concentrations and consequently a dramatic decrease in yields, the re-use of drainage water is not commonly practiced in the study region, except in tail end situations and during water scarce years. Thus, the potential of using percolated water by downstream farmers is also limited and classical water use efficiency and productivity estimations can be applicable.

The water use reduction rate (WURR) is the ratio of the potential amount of water to be reduced by each technology at field level to the water application amount under conventional practices.

Partial budget analysis [23] was employed to compare costs and benefits before and after the implementation of any water-wise option. Partial budget analyses addressed four components - Additional costs, reduced revenue, additional revenue and reduced costs. The first two components were grouped as net cost changes whereas the third and fourth components were classified as net revenue change. The difference between the net cost change and the net revenue change is the net income change due to the new technology. A value $>$ zero indicates a potential profit while values $<$ zero indicate losses, when applying the technology.

Initial investment requirement was taken as a measure of financial viability. 
To rank and classify the studied water-wise options $(t)$ according to their estimated parameters, these indicators needed to be normalized (adjusted) in relation to their maximum value.

Water use reduction rate $\left(W U R R_{t}\right)$ was adjusted relative to a maximal value (WURRmax) according to:

$$
W U R R a d j_{t}=W U R R_{t} / W U R R \max \times 100 \%
$$

where WURRadj $t$ is the adjusted value of the water use reduction rate of $t$ technology.

Adjusted values for economic efficiency $\left(E E a j_{j}\right)$ were estimated as:

$$
E_{E a d j}=E E_{t} / E E \max \times 100 \%
$$

where $E E_{t}$ is real economic efficiency of technology $t$ and EEmax is economic efficiency of the most proficient technology.

To obtain adjusted values for the financial viability $(F V a d j)$, which is mostly influenced by social changes, percentage shares of actual financial viability $\left(F V_{t}\right)$ relative to the maximum value ( $\left.F V \max \right)$ among them were subtracted from 100\%:

$$
F \text { Vadj }_{t}=100 \%-\left(F V_{t} / F V \max \right) \times 100 \%
$$

Three-dimensional bubble charts were created that allowed comparison of sets of three values according to adjusted values where WURR was set on the abscissa, financial viability (FV) was set on the ordinate and the economic efficiency (EE) was displayed as the size of the bubble marker. This approach allowed classifying the different technologies into different efficiency groups while considering concurrently the three indicators WURR, EE and FV.

\subsection{Data Collection}

Data was collected from a wide range of sources. Data on agricultural land use, production level and yield by different crops in the study region was provided by the ZEF/UNESCO project database and combined with information from the Regional Statistics Department (OblStat). The water intake and recharge from Amu Darya was provided by the Regional Water Resources Management Department (OblVodKhoz) and the ZEF/UNESCO Project. Data on the selected water-wise innovations was compiled from research carried out in different parts of Central Asia by the Central Asia Irrigation Research Institute (SANIIRI), International Water Management Institute (IWMI), and the Scientific Information Center of the Interstate Commission for Water Coordination of Central Asia (SIC-ICWC). Agricultural commodity prices were provided by the ZEF/UNESCO Project. Missing prices were provided by the regional statistical bulletins. Input prices available from former studies were adapted to the present using inflation rates.

\subsection{SWOT}

A SWOT analysis [24,25] was used for assessing existent and possible opportunities and constraints in the adoption of advanced water-wise techniques to prevent water application losses on field level. In particular two options-drip irrigation and laser-guided leveling-were evaluated based on an extended literature survey. Advantages and disadvantages of these techniques were considered as 
strengths and weaknesses that influence their attractiveness. Additionally, the stimulus to implement the technology and its potential benefits were taken as possible opportunities, while threats mean barriers in adopting the method and its potential negative consequences.

\section{Results}

The water use efficiency of each innovation varied and, hence, minimal and maximal values for water use reduction rate were determined.

\subsection{Water Productivity Change}

Relying on changed values of water usage and crop yield, water productivity was analyzed for each option (Table 1). Obviously, increased water productivity decreases saline ground water levels while making additional water available for natural uses.

Table 1. Yields, water use and water productivity of examined water-wise techniques.

\begin{tabular}{|c|c|c|c|c|c|c|c|c|c|c|c|}
\hline \multirow{2}{*}{\multicolumn{2}{|c|}{ Code Options }} & \multicolumn{2}{|c|}{ Yield, $\mathrm{kg} \mathrm{ha}^{-1}$} & \multicolumn{3}{|c|}{ Water, $\mathbf{m}^{3} \mathbf{h a}^{-1}$} & \multicolumn{3}{|c|}{$\begin{array}{c}\text { Water productivity, } \\
10^{-3} \mathrm{~kg} \mathrm{~m}^{-3} \\
\end{array}$} & \multicolumn{2}{|c|}{ Change } \\
\hline & & Actual & Changed & Actual & Min & $\max$ & Actual & Min & $\max$ & $\min$ & $\max$ \\
\hline A2 & Aerobic rice $v s$. paddy rice & 4,611 & 3,689 & 30,755 & 21,529 & 15,378 & 150 & 171 & 240 & $114 \%$ & $160 \%$ \\
\hline B1 & Hydrogel & & & & & & & & & & \\
\hline a) & Cotton & 2,543 & 2,925 & 8,000 & 5,600 & 4,000 & 318 & 522 & 731 & $164 \%$ & $230 \%$ \\
\hline b) & Wheat & 4,413 & 4,854 & 4,433 & 3,103 & 2,216 & 996 & 1,564 & 2,190 & $157 \%$ & $220 \%$ \\
\hline c) & Vegetables & 22,547 & 23,674 & 8,500 & 5,950 & 4,250 & 2,653 & 3,979 & 5,570 & $150 \%$ & $210 \%$ \\
\hline B2 & Manuring & & & & & & & & & & \\
\hline a) & Cotton & 2,543 & 3,255 & 8,000 & 7,440 & 7,040 & 318 & 438 & 462 & $138 \%$ & $145 \%$ \\
\hline b) & Wheat & 4,413 & 5,296 & 4,433 & 4,123 & 3,901 & 996 & 1,285 & 1,358 & $129 \%$ & $136 \%$ \\
\hline c) & Potato & 1,3245 & 16,791 & 8,500 & 7,905 & 7,480 & 1,558 & 2,124 & 2,245 & $136 \%$ & $144 \%$ \\
\hline $\mathrm{C} 1$ & Laser leveling (cotton) & 2,543 & 3,306 & 8,000 & 6,400 & 5,600 & 318 & 517 & 590 & $163 \%$ & $186 \%$ \\
\hline $\mathrm{C} 2$ & Drip irrigation (tomato) & 22,547 & 25,929 & 8,500 & 4,675 & 3,400 & 2,653 & 5,546 & 7,626 & $209 \%$ & $288 \%$ \\
\hline D1 & Surge flow (cotton) & 2,543 & 2,981 & 8,000 & 6,800 & 6,400 & 318 & 438 & 466 & $138 \%$ & $147 \%$ \\
\hline D2 & Double furrow (cotton) & 2,543 & 2,797 & 8,000 & 7,200 & 6,400 & 318 & 389 & 437 & $122 \%$ & $138 \%$ \\
\hline D3 & ADF (cotton) & 2,543 & 2,993 & 8,000 & 6,400 & 6,000 & 318 & 468 & 499 & $147 \%$ & $157 \%$ \\
\hline D4 & Shorter furrows (cotton) & 2,543 & 2,696 & 8,000 & 7,600 & 7,360 & 318 & 355 & 366 & $112 \%$ & $115 \%$ \\
\hline
\end{tabular}

Actual water productivity of cotton in the base case was $0.32 \mathrm{~kg} \mathrm{~m}^{-3}$, whilst a hydrogel application would increase it by $64 \%$ and $130 \%$ under the worst and best scenarios, respectively. Laser-guided land leveling would also positively impact on the water productivity by increasing it by $63-86 \%$. The water productivity of cotton was increased by $47-57 \%$ with the introduction of ADF, $38-47 \%$ by surge flow, $38-45 \%$ by manuring, $22-38 \%$ by double flow, and $12-15 \%$ by shorter furrows. The level of water productivity of tomato under drip irrigation would rise almost 2-3 times, which is the highest increase in water productivity of all the options examined. Wheat water productivity under manuring would increase by $29-36 \%$ compared to the base case $\left(0.996 \mathrm{~kg} \mathrm{~m}^{-3}\right)$ whereas a hydrogel application would bring about an increase 1.6-2.2 times of the water productivity level. Manuring potatoes would result on average in a $40 \%$ increase of water productivity. In spite of yield penalties from replacing 
paddy rice cultivation with aerobic varieties, this measure would positively impact on water productivity (14-60\% increase).

\subsection{Partial Budget Analysis}

Based on the results of the partial budget analysis (Table 2), all options except for a change in cropping pattern (A1) would result in additional benefit from the introduction of the technology.

Table 2. Results of partial budget analysis for different water-wise options. UZS = Uzbek

Soum (Average exchange rate for 2005: 1,400 UZS = 1 US\$).

\begin{tabular}{|c|c|c|c|c|c|c|c|c|}
\hline \multirow[t]{2}{*}{ Code } & \multirow[t]{2}{*}{ Options } & \multirow{2}{*}{$\begin{array}{c}\text { Additional } \\
\text { costs, } \\
\text { UZS ha }^{-1}\end{array}$} & \multirow{2}{*}{$\begin{array}{l}\text { Reduced } \\
\text { returns, } \\
\text { UZS ha }^{-1}\end{array}$} & \multirow{2}{*}{$\begin{array}{c}\text { Additional } \\
\text { returns, } \\
\text { UZS ha }^{-1}\end{array}$} & \multicolumn{2}{|c|}{$\begin{array}{c}\text { Reduced costs, } \\
\text { UZS ha }^{-1} \\
\end{array}$} & \multicolumn{2}{|c|}{$\begin{array}{c}\text { Net income change, } \\
\text { UZS ha }^{-1}\end{array}$} \\
\hline & & & & & Min & $\max$ & $\min$ & $\max$ \\
\hline A1 & $\begin{array}{l}\text { Maize } v s \\
\text { paddy rice }\end{array}$ & 156,498 & 503,852 & 0 & 638,050 & 638,050 & $-22,300$ & $-22,300$ \\
\hline A2 & $\begin{array}{l}\text { Aerobic } v s . \\
\text { paddy rice }\end{array}$ & 0 & 599,445 & 0 & 523,663 & 677,438 & $-75,783$ & 77,992 \\
\hline B1 & Hydrogel & & & & & & & \\
\hline a) & Cotton & 154,592 & 0 & 152,587 & 60,000 & 100,000 & 57,995 & 97,995 \\
\hline b) & Wheat & 161,399 & 0 & 220,657 & 33,750 & 56,250 & 93,008 & 115,508 \\
\hline c) & Vegetable & 167,517 & 0 & 281,837 & 60,000 & 100,000 & 174,320 & 214,320 \\
\hline B2 & Manuring & & & & & & & \\
\hline a) & Cotton & 242,786 & 0 & 299,070 & 31,500 & 41,500 & 87,784 & 97,784 \\
\hline b) & Wheat & 264,131 & 0 & 441,314 & 9,478 & 15,019 & 186,660 & 192,201 \\
\hline c) & Potato & 972,260 & 0 & $1,595,681$ & 14,875 & 25,500 & 638,296 & 648,921 \\
\hline C1 & Laser leveling & 287,688 & 0 & 305,174 & 68,802 & 88,802 & 86,289 & 106,289 \\
\hline $\mathrm{C} 2$ & Drip irrigation & 793,460 & 0 & 845,512 & 195,625 & 227,500 & 247,676 & 279,551 \\
\hline D1 & Surge flow & 127,516 & 0 & 175,155 & 30,000 & 40,000 & 77,640 & 87,640 \\
\hline D2 & Double flow & 60,172 & 0 & 101,725 & 20,000 & 40,000 & 61,552 & 81,552 \\
\hline D3 & $\mathrm{ADF}$ & 41,600 & 0 & 180,000 & 40,000 & 50,000 & 178,400 & 188,400 \\
\hline D4 & Short furrows & 26,103 & 0 & 61,035 & 10,000 & 16,000 & 44,931 & 50,931 \\
\hline
\end{tabular}

Replacing paddy rice areas with less water-consumptive crops such as maize for grain was not economically profitable. Aerobic rice may cause net income losses, but showed significant gains in the best scenario. Yields from aerobic could be increased further by using especially developed aerobic varieties, by producing higher quality, which in turn may gain higher prices, or by additional decreases on water demand, which all may reduce this crop's current economic inefficiency. The highest net benefit change could be obtained from manuring potato. Drip irrigation in tomato production also presented a high benefit, being the second-best option based on net income changes. Although drip irrigation is one of the most expensive water-wise technologies, high yield gains and stable, high market prices for tomatoes would contribute to high profits.

The financial viability of the water-wise options depends on the costs of their implementation, which in turn affects the acceptance by farmers, i.e., with the typically undercapitalized farms of the region, the willingness of farmers to take the risk of high initial investments is currently reduced. This 
seems to be a major reason of the lack of a more spontaneous, wider adoption of capital intensive technologies such as drip irrigation.

\subsection{Comparing the Ecological, Economic and Social Efficiency of Water-Wise Technologies}

The examined water-wise options were classified based on their attractiveness due to the water use reduction rate (indicating ecological efficiency), economic efficiency and financial viability.

If the different water efficient methods are compared while taking into account the two additional criteria - financial viability and economic efficiency (Figure 1) - the use of hydrogel and alternate dry furrow (ADF) showed the highest impact potential. Although diversifying crops and replacing paddy rice with aerobic rice are innovations that have a high potential to reduce the present high amounts of water use, their economic efficiency was very low compared to other options in spite of their high economic feasibility. Drip irrigation has the highest economic and water use efficiency, but a very low financial viability reduces its attractiveness. This is even more pronounced for laser-guided land leveling, with lower water use efficiency, economic efficiency and financial viability than drip irrigation. The shorter furrow (D4) and double flow techniques (D2) do not require much initial investment, while demonstrating a low economic and water use efficiency in comparison to other options. In general, there is a proportional relationship between water use reduction rate and capital requirement.

Figure 1. Water use reduction rate, economic efficiency, and financial viability of water conservation techniques. The size of the bubbles corresponds to economic efficiency. Note: Crop change is left blank since it gained negative gross margins.

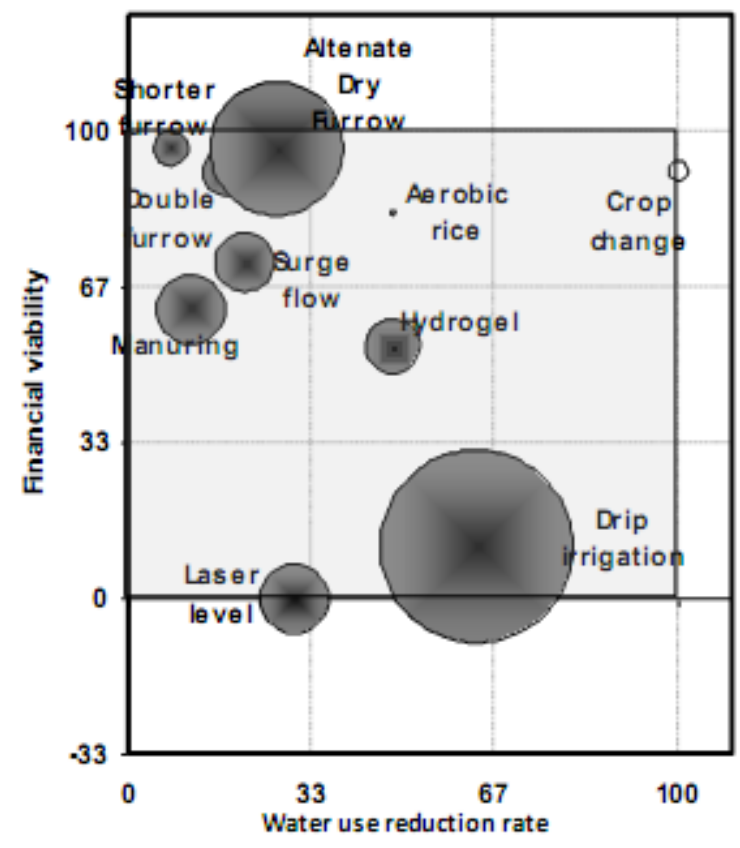




\subsection{SWOT Results}

Results of the SWOT analyses for drip irrigation and laser-guided land leveling (Table 3) showed that drip irrigation positively influenced yield, water application efficiency, labor productivity and economic efficiency while decreasing health risks and minimizing fertilizer/nutrient losses.

Table 3. SWOT analysis of implementing advanced water-wise options.

\begin{tabular}{|c|c|c|c|c|c|c|c|}
\hline & $\begin{array}{l}\text { Probability } \\
\text { of realization: } \\
\text { 3-High } \\
\text { 2-Medium } \\
\text { 1-Low } \\
\end{array}$ & $\begin{array}{l}\text { Influe } \\
\text { 3-Hig } \\
\text { 2-Med } \\
\text { 1-Lov }\end{array}$ & ium & & $\begin{array}{l}\text { Probability } \\
\text { of realization: } \\
\text { 3-High } \\
\text { 2-Medium } \\
\text { 1-Low } \\
\end{array}$ & $\begin{array}{l}\text { Influe } \\
\text { 3-Hig } \\
\text { 2-Mec } \\
\text { 1-Lon }\end{array}$ & nce: \\
\hline & & Drip & LGLL & & & Drip & LGLL \\
\hline $\begin{array}{l}\text { Strength } \\
\text { (Advantages): }\end{array}$ & & & & $\begin{array}{l}\text { Weakness } \\
\text { (Disadvantages): }\end{array}$ & & & \\
\hline * Increases crop yield & 3 & 3 & 2 & $\begin{array}{l}\text { * High initial } \\
\text { investment cost }\end{array}$ & 3 & 3 & 3 \\
\hline $\begin{array}{l}\text { * Increases labor } \\
\text { productivity }\end{array}$ & 3 & 3 & 1 & $\begin{array}{l}* \text { Requires skilled } \\
\text { labor }\end{array}$ & 3 & 3 & 3 \\
\hline * Decreases health risk & 2 & 2 & - & $\begin{array}{l}* \text { Additional } \\
\text { O\&M cost }\end{array}$ & 3 & 2 & 2 \\
\hline $\begin{array}{l}\text { * Uniform water } \\
\text { distribution }\end{array}$ & 3 & 3 & 3 & $\begin{array}{l}* \text { Requires } \\
\text { qualitative water }\end{array}$ & 3 & 2 & - \\
\hline $\begin{array}{l}\text { * Permits economize } \\
\text { water }\end{array}$ & 3 & 3 & 2 & * Waste & 2 & 3 & - \\
\hline $\begin{array}{l}\text { * High economic } \\
\text { efficiency }\end{array}$ & 3 & 3 & 2 & $\begin{array}{l}* \text { Clogging of } \\
\text { emitters }\end{array}$ & 2 & 3 & - \\
\hline $\begin{array}{l}\text { * Minimized fertilizer } \\
\text { loss }\end{array}$ & 3 & 3 & 1 & & & & \\
\hline \multicolumn{4}{|c|}{ Opportunities (Incentives): } & \multicolumn{2}{|c|}{ Threats (Constraints): } & & \\
\hline Economic: & & & & Economic: & & & \\
\hline $\begin{array}{l}\text { * Increased } \\
\text { agricultural } \\
\text { commodity prices }\end{array}$ & 3 & 3 & 2 & $\begin{array}{l}\text { * Underdevelopment } \\
\text { of market } \\
\text { infrastructure }\end{array}$ & 3 & 3 & 3 \\
\hline $\begin{array}{l}* \text { Resolves food } \\
\text { security issues }\end{array}$ & 2 & 3 & 2 & $\begin{array}{l}\text { * Dependence on } \\
\text { import }\end{array}$ & 3 & 2 & 3 \\
\hline $\begin{array}{l}\text { * Contributes to } \\
\text { economic growth by } \\
\text { increasing yields }\end{array}$ & 2 & 2 & 2 & $\begin{array}{l}\text { * Lack of fund to } \\
\text { extend modern } \\
\text { technology }\end{array}$ & 3 & 3 & 3 \\
\hline $\begin{array}{l}\text { * Low agriculture } \\
\text { prices will be } \\
\text { maintained }\end{array}$ & 2 & 2 & 2 & $\begin{array}{l}* \text { Lack of economic } \\
\text { incentives for } \\
\text { efficient water } \\
\text { using }\end{array}$ & 3 & 3 & 3 \\
\hline
\end{tabular}


Table 3. Cont.

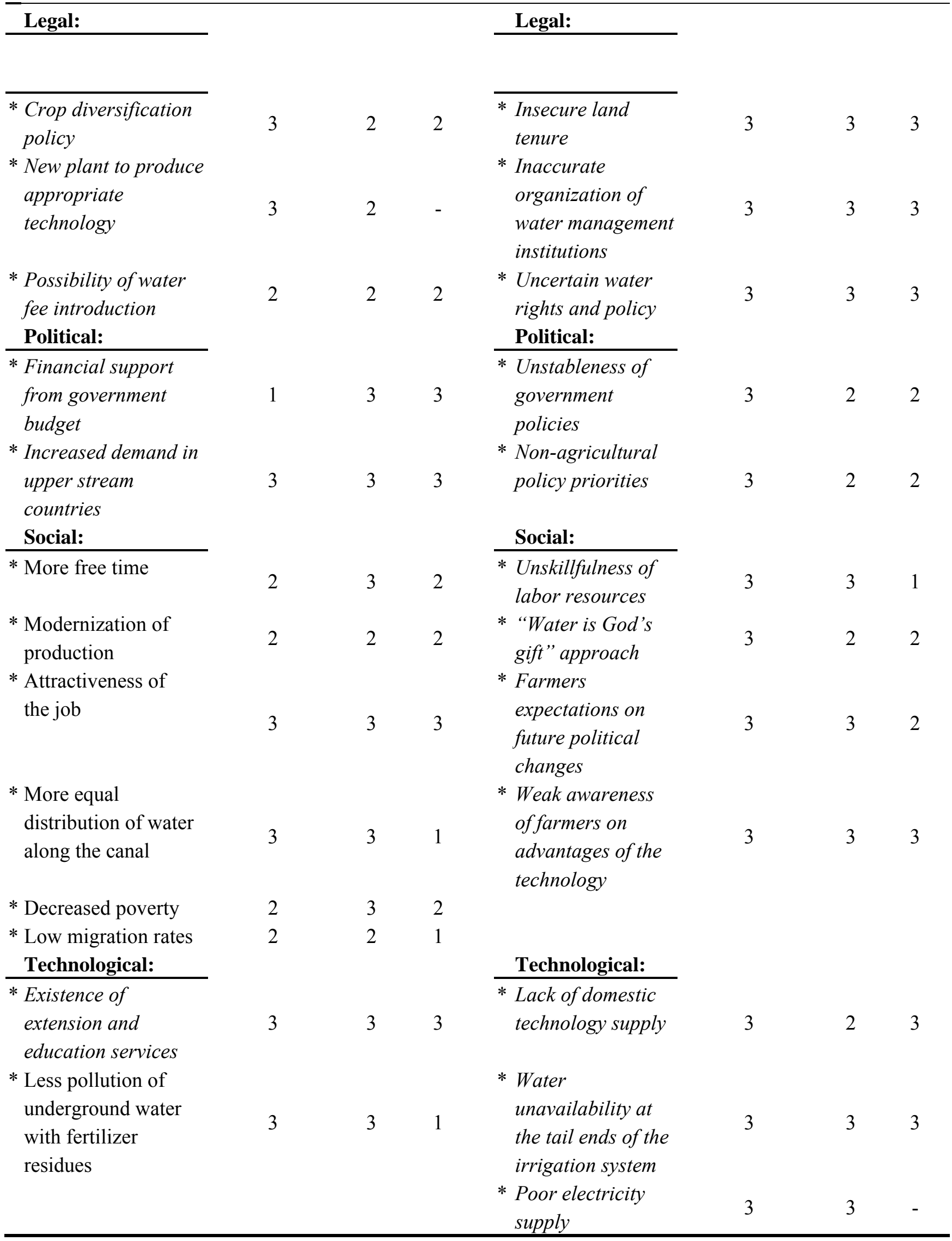


However, the use of drip irrigation in cotton production requires high capital investment costs, skilled labor in operation and the availability of high quality water [26]. Additionally, the high UV radiation that prevails throughout the growing season shortens the usable lifetime of the tubes used for drip irrigation. Irregular installment and clogging of emitters because of muddy water or salt accumulation may cause poor water distribution along the drip laterals and this affects plant growth, and in turn decreases the overall efficiency of the drip system.

Laser-guided land leveling allows reducing considerable amounts of water use because of a more uniform water distribution over the field [27]. This is due to the effective smoothening of the soil surface, which in turn reduces not only the irrigation duration and amounts of water applied to a field but also the requested labor. In addition, this method has several benefits as it causes a more uniform germination and growth of crops, and a reduction in fertilizer, chemicals and fuel use [27]. Often cited shortcomings are the high initial investment cost and the need for skilled laborers that can correctly set/adjust laser settings and operate the tractors [27].

Opportunities of and threats for adoption are briefly analyzed in the discussion section.

\section{Discussion: Opportunities and Constraints in Adoption of Water-Wise Irrigation Technologies}

Surge flow requires considerable investment, whereas having moderate water use reduction rate and economic potential. The method was applied widely in the USA, but we could not find recent studies on surge flow use in Central Asia. Although short and double flow techniques improve water use only slightly compared to the other options, they have a high potential in irrigated cotton production due to their insignificant implementation costs. They are especially recommended to those farmers with poor assets and in the first years of a modernization of the irrigation network. The same is true for the alternate dry furrow system, which has the potential to reduce water use on the one hand and gain profits on the other. Increasing the farmer's awareness of the benefits of these methods is therefore important to achieve improvements in the short term, as in particular, extension services in Uzbekistan are virtually absent [28].

Hydrogel application has restricted potential. Since there are at present no production facilities in Uzbekistan, this material would need to be imported. Also, most experimental results stem from the more humid areas in Uzbekistan, while experiments under the dryer conditions that prevail in the Khorezm region are required to reveal the true regional performance of hydrogel.

Manuring may lead to high yields while significantly improving water use and increasing soil productivity, and economic efficiency. However, manure application is restricted due to an insufficient supply by the underdeveloped livestock sector [29]. Government measures on supporting the livestock sector have been initiated in 2008, but have not yet seen visible effects on the ground.

Growing maize for grain could replace rice in conditions of increased yields of maize. Maize could also become an interesting crop for fodder production, although this is presently hampered by the state procurement system [29]. The underdevelopment of the livestock sector may be mainly due to a lack of trust farmers have in reaping long-term benefits of this line of production. This lack of trust is fuelled by the present non-transparent institutional and economic framework and a high degree of government intervention in agriculture [29]. 
The same can be said for the non-existence of incentives to introduce high-cost water-wise options such as laser-guided leveling and drip irrigation (Table 3). The underdevelopment of farmer-to-market links in the study region reduces the chances for farmers to obtaining adequate prices [30]. The lack of funds to extend advanced technologies, difficulty in access to bank credits and dependence on technology imports obstruct sustainable implementation. Another reported problem connected to the lack of economic incentives of rational water use is the inadequate water pricing, which at present does not encourage farmers to effectively use water [13].

An improved legal framework has been mentioned as a precondition to implement cost-intensive methods, e.g., including more profitable fruit and vegetable production in the cropping plans [31]. This conclusion is in line with recently initiated governmental support to promote a domestic plant producing drip irrigation equipment and the introduction of an effective water charging system. But insecure land tenure, uncertain water rights and policy, undefined rights and responsibilities of water management organizations presently impede a successful development of various innovations [29].

The expected increase in water demand in upstream countries should be an incentive to implement water conservation approaches downstream [3]. On the other side, changes in the laws and policy, high priority to the development of other sectors rather than agriculture, and lack of coordination among administrative organizations (ministries, water management organizations, farmers, extension services) have been shown to constrain these opportunities [13,29].

From a social perspective, implementing advanced water-wise options would lead not only to a more uniform distribution of water along the irrigation canal, but also decrease labor demand, which could be used for leisure as well as for searching additional activities for income generation such as in the agro-processing and trade sector, which can also contribute to easing poverty and lowering the present high seasonal migration rates [32]. A stepping up of the agricultural production may also render the prestige and attractiveness of irrigation and agriculture among youth [6]. In addition, several studies showed that the introduction of technologies often demands financial resources for education and training [28]. The general unwillingness of perceiving water as a tradable good reportedly also hinders implementing water efficient measures [13]. The farming population has little knowledge about further changes on land and water allocation policy. Moreover, due to restricted access to information, there is a general unawareness of producers on the (dis)advantages of yield enhancing and water efficient technologies [28].

Considering the fact that about $70 \%$ of the total cropped area of 270,000 ha in Khorezm is roughly (unevenly) leveled [33], laser-guided land leveling could be extremely suitable for the region. Since the present estimates are based on the assumption that every farmer purchases his own laser and leveling equipment, the introduction of such equipment needs to be well-organized. Since laser-guided land leveling equipment requires high initial investments, and the equipment can be used only during a few weeks prior to planting, it would be more rational to purchase this equipment on a communal basis and make it available to farmers, for instance through structures such as the MTP, farmer association, or extension services. An alternative to cooperative ownership and widespread training in the correct use of the laser leveling equipment is the involvement of private entrepreneurs, which could even be farmers, who could establish contracts with others for laser leveling their fields, since the technology has a high potential to boost the income of producers. 
Although the national administration has declared an interest in agriculture, the need for accessible, locally-made implements is presently underestimated, and should receive much more attention. At present, the majority of the farming population has to rely on small and medium sized private entrepreneurs (SMEs) for any equipment. Unfortunately, in spite of the acknowledged importance of the role of these services in the national economy, this sector is only marginally supported and motivated by governmental programs [28]. Moreover, critical services may provide employment opportunities to jobless rural youths and employment in small-scale manufacturing and transport related sectors as also seen in India [34]. Furthermore, the benefits of new technologies can reach farmers if costs for the equipment and its rental are lowered, which could be achieved by various subsidy schemes. This is justified also since water-wise technologies would benefit the environment and improve the overall productivity, which should be in the interest of farmers and administrators.

\section{Summary and Conclusions}

The employed socio-economic analyses showed that there is an inverse relationship between water use improvement potential and financial feasibility of various water-wise options, e.g., the more water-efficient the technology is, the more capital intensive it becomes. Considering the typical capital limitations of small-scale farmers in the study region, Khorezm, where modernization is just beginning, low capital intensive but less water efficient measures such as double flow, short and alternate dry furrow techniques have the highest potential to be adopted. This would allow not only for an initial widespread adoption, but these innovations can later successively be replaced by more productive - but also more expensive - technologies. Capital intensive options could at present be initialized in home gardens, greenhouses, and private household plots. Currently, there is no regionally differentiated incentive system, e.g., a system which would give incentives to implement high-cost water-wise options in the water-rich upstream regions where farmers are better off. Thus, the highest changes of success are to be expected with the introduction of water-wise options to middle level water users.

The SWOT analysis demonstrated that the existent social and economic hurdles, especially the lack of skillful specialists, the instability of incomes, and dysfunctional water management structures, could substantially hinder the adoption of any water-wise options. But there are also potential incentives that cannot be introduced to increase the chances of adoption of for instance drip irrigation and laser leveling such as increased market commodity prices, an increasing comparative advantage of crops grown in the region, a national crop diversification policy, and a more even distribution of water along the canals. Additionally, the decrease of prices for machinery and production technologies on the world market, due to the current global crisis, creates opportunities for Uzbekistan to modernize the agricultural sector. As our calculations considered the financial viability of laser guided land leveling only for an individual farmer, the potential exists for stimulating the establishment of land leveling service SMEs that are more cost effective. This option would demand, however, additional support from the national administration since the state still has strong influence on all farm-level decision-making. 


\section{Acknowledgements}

The German Ministry for Education and Research (BMBF; project number 0339970A) and the Ministry for Schools, Science and Research of the State of Northrhine-Westfalia funded this study. This paper includes research results made possible by the ZEF/UNESCO project "Economic and Ecological Restructuring of Land- and Water Use in the Khorezm Region (Uzbekistan): A Pilot Project in Development Research".

\section{References}

1. Cai, X.; McKinney, D.C.; Rosegrant, M.W. Sustainability Analysis for Irrigation Water Management in the Aral Sea Region. Agr. Syst. 2003, 76, 1043-1066; Available online: http://www.sciencedirect.com/science?_ob=MImg\&_imagekey=B6T3W-45TTMWY-1-11\&_cdi $=4957 \&$ _user $=1848530 \&$ pii $=$ S0308521X02000288\&_orig $=$ search\&_coverDate $=06 \% 2 \mathrm{~F} 30 \% 2 \mathrm{~F}$ 2003\&_sk=999239996\&view $=c \& w c h p=d G L b V z W-z S k z k \& m d 5=1558 a b d 7 e 136 e b 8 a 0 b 45 c e a d$ 4bb2a274\&ie=/sdarticle.pdf (accessed on 1 April 2010).

2. Müller, M. A General Equilibrium Approach to Modeling Water and Land Use Reforms in Uzbekistan; Ph.D. Thesis; Bonn University: Bonn, Germany, May 2006; pp. 15-44.

3. Central Asia: Water and Conflict; Asia Report No.34; International Crisis Group (ICG): Brussels, Belgium, 2002.

4. Abdullayev, I.; Nurmetova, F.; Abdullaeva, F.; Lamers, J. Socio-Technical Aspects of Water Management in Uzbekistan: Emerging Water Governance Issues at the Grass Root Level. In Central Asian Waters; Rahaman, M.M., Varis, O., Eds.; Helsinki University of Technology: Helsinki, Finland, 2008; pp. 89-103.

5. Abdullayev, I.; Kazbekov, J.; Molden, D. Water Conservation Practices in the Syr Darya Basin of Central Asia: Water Productivity Impacts and Alternatives. Int. Water Irrig. J. 2007, 2, 14-17.

6. Khamraev, N.; Dzhalalov, S. Economics of Water Saving Technologies in Uzbekistan; Mekhnat: Tashkent, Uzbekistan, 1990.

7. Report on Water Conservation Costs of Different Water-Wise Options; Central Asian Research Institute of Irrigation (SANIIRI): Tashkent, Uzbekistan, (Unpublished Work).

8. Glazirin, G.E.; Chanishev, S.G.; Chub, V.E. Short Overview of the Climate in Uzbekistan; Chinor ENK-Galaba: Tashkent, Uzbekistan, 1999; p. 29.

9. Socio-Economic Indicators for the Khorezm Region in 2007; Regional Statistical Department Khorezm (OblStat): Urgench, Uzbekistan, 2008.

10. Water Use in Khorezm Region in 2000-2008; UPRADIK Technical Report; Amudarya Interstate Canal Authority (UPRADIK): Urgench, Uzbekistan, 2008.

11. Duhovny, B.A; Sorokin, A.G. Assessing the Impact of Rogun Water-Reservoir on Amu Darya River Flow Frequency; Interstate Commission for Water Coordination (ICWC): Tashkent, Uzbekistan, 2007. 
12. Martius, C.; Froebrich, J.; Nuppenau, E.A. Water Resource Management for Improving Environmental Security and Rural Livelihoods in the Irrigated Amu Darya Lowlands. In Facing Global Environmental Change: Environmental, Human, Energy, Food, Health and Water Security Concepts; Hexagon Series on Human and Environmental Security and Peace; Brauch, H.G., Oswald Spring, U., Grin, J., Mesjasz, C., Kameri-Mbote, P., Chadha Behera, N., Chourou, B., Krummenacher, H., Eds.; Springer-Verlag: Berlin, Germany, 2009; Volume 4, pp. 749-762.

13. Bobojonov, I. Modeling Crop and Water Allocation under Uncertainty in Irrigated Agriculture: A Case Study on the Khorezm Region, Uzbekistan; Ph.D. Thesis; Bonn University: Bonn, Germany, 12 December 2008.

14. Ibrakhimov, M. Spatial and Temporal Dynamics of Groundwater Table and Salinity in Khorezm (Aral Sea Basin), Uzbekistan; ZEF Series in Ecology and Development, No. 23; Bonn University: Bonn, Germany, 2005; p. 175.

15. Saravanan, V.S. A System Approach to Unravel Complex Water Management Institutions. Ecol. Complex. 2008, 5, 202-215; Available online: http://www.sciencedirect.com/science? _ob=ArticleURL\&_udi=B7CRV-4ST4CF9-1\&_user $=1848530 \&$ coverDate $=09 \% 2 \mathrm{~F} 30 \% 2 \mathrm{~F} 2008$ \&_rdoc $=1 \&$ fmt $=$ high\&_orig $=$ search\&_sort $=\mathrm{d} \&$ _docanchor $=$ \&view $=\mathrm{c} \&$ _acct $=\mathrm{C} 000055082$ \&_v ersion=1\&_urlVersion=0\&_userid=1848530\&md5=e1bc913679689454ff7d6d602aa5dc47 (accessed on 1 April 2010).

16. Wegerich, K. Water User Associations in Uzbekistan and Kyrgyzstan: Study on Conditions for Sustainable Development; Occasional Paper No. 32; Water Issues Study Group, School of Oriental and African Studies (SOAS), University of London: London, UK, 2000.

17. Abdullayev, I.; U1 Hassan, M.; Manthrithilake, H.; Yakubov, M. The Reliability Improvement in Irrigation Services: Application of Rotational Water Distribution to Tertiary Canals in Central Asia; IWMI Research Report 100; International Water Management Institute (IWMI): Colombo, Sri Lanka, 2006; p. 28.

18. Molden, D.; Tharme, R.; Abdullaev, I.; Puskar, R. Irrigation. In Farming with Nature: The Science and Practice of Ecoagriculture; Scherr, S., McNeely, J., Eds.; Island Press: Washington DC, USA, 2007; pp. 231-249.

19. Bucknall, L.; Klytchnikova, I.; Lampietti, J.; Lundell, M.; Scatasta, M.; Thurman, M. Irrigation in Central Asia: Social, Economic and Environment Considerations; World Bank: Washington, DC, USA, 2003.

20. Information on WUAs in the Khorezm Region; Regional Department of Water Users Associations (RWUA): Urgench, Uzbekistan, 2006.

21. Zavgorodnyaya, D. WUAs in Uzbekistan: Theory and Practice; Ph.D. Thesis; Bonn University: Bonn, Germany, 12 June 2006.

22. Veldwisch, G.J.A. Cotton, Rice \& Water: The Transformation of Agrarian Relations, Irrigation Technology and Water Distribution in Khorezm, Uzbekistan; Ph.D. Thesis; Bonn University: Bonn, Germany, 2 June 2008.

23. Dalsted, N.L.; Gutierrez, P.H. Partial Budgeting; Available online: http://agecon.uwyo. edu/RiskMgt/financialrisk/Partial\%20Budgeting.pdf (accessed on 25 March 2010). 
24. Voudouris, K. Optimization of Water Resources Management Using SWOT Analysis: The Case of Zakynthos Island, Ionian Sea, Greece. Environ. Geol. 2008, 54, 197-211.

25. Richards, H. Modeling and Decision Support Tools; Department of Engineering, University of Cambridge: Cambridge, UK, 2001; Available online: http:/www.ifm.eng.cam.ac.uk/dstools/ paradigm/swot.html (accessed on 10 February 2008).

26. Ibragimov, N.; Evett, S.; Esanbekov, Y.; Kamilov, B.; Mirzaev, L.; Lamers, J.P.A. Water Use Efficiency of Irrigated Cotton in Uzbekistan under Drip and Furrow Irrigation. Agr. Water Manage. 2007, 90, 112-120.

27. Abdullayev, I.; Ul Hassan, M.; Jumaboev, K. Water Saving and Economic Impacts of Land Leveling: The Case Study of Cotton Production in Tajikistan. Irrig. Drain. Syst. 2007, 21, 251-263.

28. Bekchanov, M.; Kan, E.; Lamers, J.P.A. Options of Agricultural Extension Provision for Rural Development in Central Asian Transition Economies: The Case of Uzbekistan. In Proceedings of the International Conference on Research for Sustainable Development, Tashkent, Uzbekistan, 14 May 2009; Westminster International University Tashkent: Tashkent, Uzbekistan, 2009; pp. 7181.

29. Djanibekov, N. A Micro-Economic Analysis of Farm Restructuring in Khorezm Region (Uzbekistan); Ph.D. Thesis; Bonn University: Bonn, Germany, 15 May 2008.

30. Bobojonov, I; Lamers, J.P.A. Analysis of Agricultural Markets in Khorezm, Uzbekistan. In Continuity and Change: Land and Water Use Reforms in Rural Uzbekistan-Socio-Economic and Legal Analyses for the Region Khorezm; Wehrheim, P., Schoeller-Schletter, A., Martius, C., Eds.; Leibniz Institute of Agricultural Development in Central and Eastern Europe (IAMO): Halle, Germany, 2008; Volume 43, pp. 165-182.

31. Bobojonov, I.; Rudenko, I.; Lamers, J.P.A. Optimal Crop Allocation and Consequent Ecological Benefits in Large-Scale (Shirkat) Farms in Uzbekistan's Transition Process. In Continuity and Change: Land and Water Use Reforms in Rural Uzbekistan-Socio-Economic and Legal Analyses for the Region Khorezm; Wehrheim, P., Schoeller-Schletter, A., Martius, C., Eds.; Leibniz Institute of Agricultural Development in Central and Eastern Europe (IAMO): Halle, Germany, 2008; Volume 43, pp. 63-85.

32. Conliffe, A. The Combined Impacts of Political and Environmental Change on Rural Livelihoods in the Aral Sea Region of Uzbekistan; Ph.D. Thesis; Department of Geography and Environment, University of Oxford: Oxford, UK, 2010.

33. Water-Critical Resource for Uzbekhistan's Future; United Nations Development Program (UNDP): Tashkent, Uzbekistan, 2007; pp. 38-60.

34. Gupta, R.K.; Sayre, K. Conservation Agriculture in South Asia. J. Agr. Sci. 2007, 145, 207-214.

(C) 2010 by the authors; licensee MDPI, Basel, Switzerland. This article is an Open Access article distributed under the terms and conditions of the Creative Commons Attribution license (http://creativecommons.org/licenses/by/3.0/). 